\section{CHANGES IN TUMOR NECROSIS FACTOR IN POSTPNEUMONECTOMY LUNG GROWTH}

So that changes in production and binding of tumor necrosis factor-alpha during postpneumonectomy lung growth could be determined, rats underwent left lung resection and were killed 3, 7, or 14 days later, 1 hour after the injection of ${ }^{3} \mathrm{H}$-thymidine. Serum was collected, and the lungs were lavaged and perfused in vitro. Lung volumes were measured. Lungs were homogenized, and changes in Iung weight, protein content, deoxyribonucleic acid content, deoxyribonucleic acid synthesis, and tyrosine kinase activity of different lobes were recorded. Tumor necrosis factor-alpha content of serum, lavage fluid, and perfusate was measured by an enzymelinked immunoassay. The binding of tumor necrosis factor-alpha to membrane extracts of lung homogenates was measured by immunoblots. Whereas the cardiac lobe of the remaining right lung demonstrated larger increases in size than other lobes after pneumonectomy, there was no difference in any growth parameter between it and the other lung lobes. Serum tumor necrosis factor-alpha was detectable in sham-operated animals and increased significantly after pneumonectomy. However, by day 14, it was not different from the level in sham-operated animals. In contrast, tumor necrosis factor-alpha in lavage fluid remained significantly elevated, and its binding increased gradually throughout the study period. Tumor necrosis factor-alpha in perfusate did not demonstrate any rise. We conclude that lung growth after pneumonectomy is uniform among various lobes, which suggests that it is regulated by humoral factors. Because tumor necrosis factor-alpha, a cytokine known to stimulate cellular proliferation and matrix synthesis, is produced and bound to the lung during this process, it may be one of the humoral factors implicated in postpneumonectomy lung growth. (J THORAC CaRDIOvasC SuRg 1995;110:396-404)

B. A. Dubaybo, MD, G. Bayasi, MD, and G. J. Rubeiz, MD, Detroit, Mich.
A lthough lung growth is primarily a perinatal event in human beings, ${ }^{1-4}$ some degree of lung growth continues to occur in adolescence. ${ }^{4-6}$ The adult lung, however, is relatively stable, with minimal turnover of cells. ${ }^{1}$ Fortunately, the adult lung retains its latent growth potential, which may be-

From the Division of Pulmonary and Critical Care Medicine, Medical Service, Veterans Administration Medical Center, Allen Park, and Wayne State University School of Medicine, Detroit, Mich.

This work was supported by Medical Research funds of the Deparmtent of Veterans Affairs and the Fund for Medical Research and Education of the Department of Internal Medicine, Wayne State University School of Medicine.

Received for publication Sept. 2, 1994.

Accepted for publication Dec. 20, 1994.

Address for reprints: Basim A. Dubaybo, MD, Medical Service (111A), VAMC, Allen Park, MI 48101.

$12 / 1 / 63010$ come manifest in response to lung injury. ${ }^{4-7}$ Because this growth occurs in the setting of acute loss of functioning lung units, it is labeled "compensatory lung growth." The ability of the adult lung to undergo compensatory growth after partial pneumonectomy has been extensively evaluated. Most of the work has been conducted in animals and has shown significant growth within weeks of surgery. ${ }^{7-13}$ Although human data are scanty, limited physiologic studies confirm that some degree of growth does occur. ${ }^{5,12}$ An understanding of the mechanisms that regulate such growth may lead to the development of therapeutic modalities that can accelerate growth and decrease postresection morbidity. This study focused on the role of tumor necrosis factor-alpha (TNF- $\alpha$ ) and investigated whether it is involved in postpneumonectomy compensatory lung growth.

TNF- $\alpha$ is an alveolar macrophage-derived cytokine with diverse toxic, antitumor, mitogenic, and 
immunoregulatory functions. ${ }^{14-17}$ It has been demonstrated to influence cellular proliferative responses, as well as cellular synthetic functions. These properties have implicated TNF- $\alpha$ in the regulation of growth in general and of lung growth in particular. For example, Hass and associates ${ }^{18}$ demonstrated that mouse fibroblasts have specific high-affinity receptors for TNF- $\alpha$ and that binding of TNF- $\alpha$ to these receptors initiates a series of events resulting in modulation of the growth characteristics of these cells. Sugarman, Hass, and Figari $^{19}$ demonstrated increased fibroblast proliferation in normal human and murine lung fibroblasts exposed to TNF- $\alpha$. Elias and coworkers ${ }^{20}$ demonstrated an increase in synthesis of glycosaminoglycans in human lung fibroblasts exposed to TNF- $\alpha{ }^{20}$ The ability of TNF- $\alpha$ to influence cellular proliferation and matrix deposition has led investigators to postulate a role for this cytokine in the regulation of lung growth and repair. In fact, such a role has previously been reported in the bleomycin model of lung repair. ${ }^{21,22}$ Numerous investigators have implicated humoral factors in the modulation of postpneumonectomy lung growth. ${ }^{23-27}$ The possible role of TNF- $\alpha$ in this process has not been addressed. To investigate this possibility, we examined changes in TNF- $\alpha$ production and binding during postpneumonectomy lung growth.

\section{Materials and methods}

The experimental model. Left pneumonectomy was performed on adult male Fischer 344 rats (175 to $200 \mathrm{gm}$ ) as follows. Rats were anesthetized with methohexital ( 85 $\mathrm{mg} / \mathrm{kg}$ ), intubated under direct vision with the use of a 16-gauge cannula, and connected to a volume-cycled rodent ventilator delivering a tidal volume of $10 \mathrm{ml} / \mathrm{kg}$ at a rate of 80 to 100 breaths/min. The left side of the chest was cleaned with a detergent, shaved, and sterilized with povidone-iodine (Betadine). A $1 \mathrm{~cm}$ horizontal skin incision was made over the fourth intercostal space and extended into the pleural cavity. The ribs were held apart by a sterile self-retaining retractor. The exposed left lung was held with blunt forceps and gently pulled out of the thoracic cavity. After the hilum was visualized, a tie was placed around it, occluding the left main-stem bronchus and the major blood vessels supplying that lung. After tightening of the tie, the left lung was resected just distal to the knot. The thoracic cavity was then closed with two layers of suture lines. In general, the procedure was bloodless. If bleeding into the pleural cavity occurred during the operation, the animal was killed immediately and not used in this study.

Sham operations were performed by the same procedure. After the left lung was exposed, a continuous suture line was applied to the chest wall but not tightened. The exhalation port of the ventilator was occluded for three breaths to allow the left lung to reexpand, and then the suture was tightened and the chest cavity closed. This technique allowed reexpansion of the lung with no risk of pneumothorax. Some animals were put to death without undergoing any procedure and served as controls. These procedures were reviewed and approved by the animal investigation committees of the two institutions. All animals used in this study received humane care in compliance with the "Principles of Laboratory Animal Care" formulated by the National Society for Medical Research and the "Guide for the Care and Use of Laboratory Animals" prepared by the Institute of Laboratory Animal Resources and published by the National Institutes of Health (NIH Publication No. 86-23, revised 1985).

After pneumonectomy or sham operation, the animals were allowed to recover from anesthesia and given food and water adlibitum. Groups of animals were killed 3, 7, or 14 days later, and a number of growth parameters were measured.

Measurement of growth parameters. Each rat was injected with ${ }^{3} \mathrm{H}$-thymidine $(1 \mathrm{mCi} / \mathrm{kg}$, intravenously). One hour later, the rat was killed and total blood was collected by a direct cardiac puncture, with trisodium citrate used as an anticoagulant. The chest wall was opened, and the exposed lung was perfused intravenously with $10 \mathrm{ml}$ of normal saline solution. The right lung was then excised, and the cardiac lobe (C) was identified and separated from the three other lobes ( $\mathrm{R})$. The following measurements were then obtained from both $\mathrm{C}$ and $\mathrm{R}$ by the techniques described.

Dry lung weight. Measured portions of lung tissues were dried in an oven at $66^{\circ} \mathrm{C}$ and weighed daily until there was no further reduction in lung weight. The final measurement obtained was considered the dry weight of that portion of the lung. Dry-to-wet ratio was determined, and total dry weight was quantitated by multiplying the dryto-wet ratio by the total wet weight.

Lung deoxyribonucleic acid (DNA) content. Measured portions of lung tissue were homogenized in a buffer consisting of $10 \mathrm{mmol} / \mathrm{L}$ HEPES ( $\mathrm{pH} 7.2$ ), $150 \mathrm{mmol} / \mathrm{L}$ sodium chloride, and $1 \mathrm{mmol} / \mathrm{L}$ magnesium chloride. DNA was then extracted by Burton's method of repetitive acid precipitation and measured spectrophotometrically at a wavelength of $600 \mathrm{~nm}$ by means of the previously described diphenylamine technique. ${ }^{28}$ Total DNA was then arithmetically extrapolated.

DNA synthesis. Because the newly synthesized DNA had already been radiolabeled with ${ }^{3} \mathrm{H}$-thymidine, the rate of synthesis was determined by measuring the emission from extracted DNA with a beta counter. DNA synthesis was expressed as counts per minute per milligram of lung DNA.

Tyrosine kinase activity. The activity of this cell membrane enzyme, which is an early marker of cellular proliferative activity, was determined as follows. A measured portion of lung tissue was homogenized in the previously described buffer and then passed through glass wool to adsorb the lipid fraction. Cell membranes were separated from homogenized lung tissue by centrifugation. Total protein content of this membrane fraction was determined spectrophotometrically at a wavelength of $595 \mathrm{~nm}$ by the method of Bradford. ${ }^{29}$ Tyrosine kinase activity of 


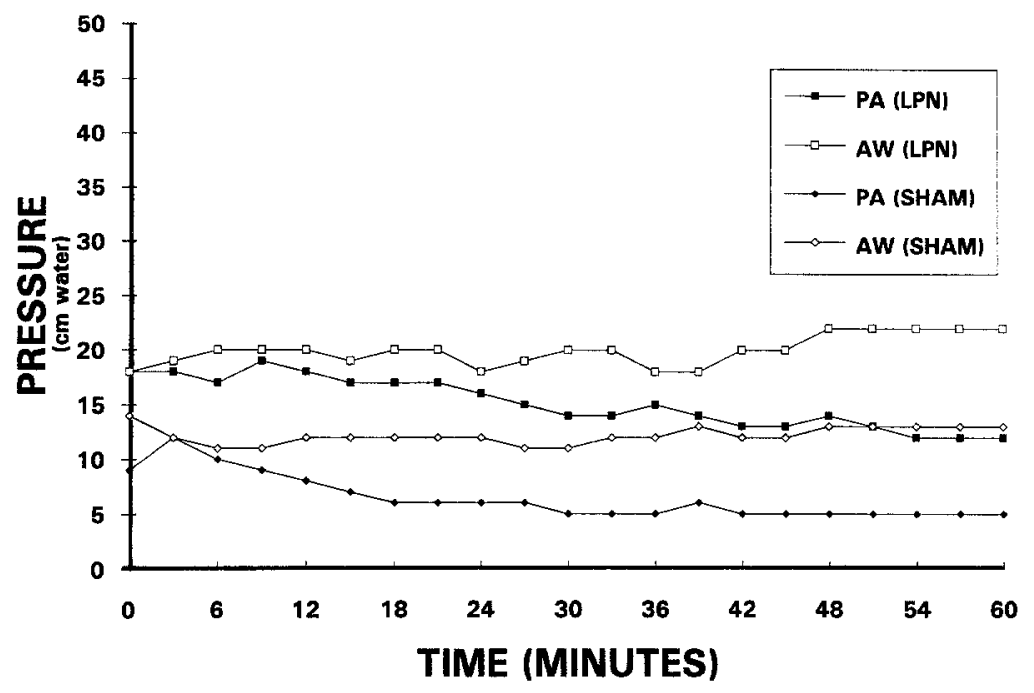

Fig. 1. Changes in pulmonary artery and airway pressure recordings during 1 hour of in vitro ventilation and perfusion of a sham-operated and a postpneumonectomy lung. $P A$, Pulmonary artery, $A W$, airway, $L P N$, left pneumonectomy.

measured amounts of membrane protein was determined by quantifying the rate of incorporation of ${ }^{32} \mathrm{P}$-labeled adenosine triphosphate into a tyrosine polymer after a 10-minute incubation at room temperature, as described previously. ${ }^{30}$ Tyrosine kinase activity was expressed as picomoles of ${ }^{32}$ P-labeled adenosine triphosphate per milligram of membrane protein.

Lung protein content. Lung proteins were extracted by trichloroacetic acid precipitation of homogenized lung tissue. Measured portions of lung tissue were homogenized in the previously described buffer. An equal volume of iced $10 \%$ trichloroacetic acid was added, and the mixture was incubated at $4^{\circ} \mathrm{C}$ for 30 minutes. The mixture was then centrifuged, and the precipitate containing denatured proteins was collected and dissolved in warm $1 \mathrm{~N}$ sodium hydroxide. The protein content of the solution was measured spectrophotometrically at a wavelength of 595 $\mathrm{nm}$ by Bradford's technique. ${ }^{29}$ Total protein content was extrapolated arithmetically and expressed as milligrams of protein per milligram of DNA.

Lung volumes. A separate group of animals was used for the measurement of lung volumes. On day 14 after the operation, lungs were fixed by the intratracheal instillation of $10 \%$ formaldehyde at an inflation pressure of $20 \mathrm{~cm}$ of the liquid fixative. After 20 minutes of fixation, the trachea was tied and the whole right lung was removed en bloc. C was separated from $R$, and the volume of each was determined by water displacement.

Determination of TNF- $\alpha$ production after pneumonectomy. A separate set of animals was used for TNF- $\alpha$ studies.

In vitro lavage and perfusion of lungs. On days 3,7 , or 14 after operation, rats were killed and serum collected as described. A tracheostomy was performed, and the lungs were lavaged with $50 \mathrm{ml}$ of phosphate-buffered saline. In sham-operated animals, the left hilum was ligated before lavage. Lavaged lungs were transferred to a water-jacketed bottle maintained at $37^{\circ} \mathrm{C}$. The pulmonary artery was cannulated and perfused with warm minimal essential medium supplemented with $6 \%$ bovine serum albumin for 1 hour at a flow rate of $200 \mathrm{ml} / \mathrm{min}$. Pulmonary artery pressure was measured and recorded during the perfusion (Fig. 1). The lungs were concomitantly ventilated with room air at 80 breaths $/ \mathrm{min}$ at a tidal volume of $10 \mathrm{ml} / \mathrm{kg}$. Airway pressure was monitored and recorded during the 1-hour incubation (see Fig. 1). Lungs that showed sudden elevation in pulmonary artery or airway pressure (indicating the possible development of pulmonary edema) were not used in the study. Phenylmethylsulfonyl fluoride was added to the perfusates and the lavage fluids, which were stored at $-70^{\circ} \mathrm{C}$ until assayed for TNF- $\alpha$. Lavaged and perfused lungs were frozen in liquid nitrogen until used for TNF- $\alpha$ receptor binding assays.

Measurement of $T N F-\alpha$ production. An indirect enzyme-linked immunosorbent assay for the measurement of small amounts of TNF- $\alpha$ was developed by us using mouse TNF- $\alpha$, goat-antimouse TNF- $\alpha$ antibody, and rabbit-antigoat immunoglobulin $\mathrm{G}$ conjugated to horseradish peroxidase (all from Calbiochem, San Diego, Calif.). The amount of TNF- $\alpha$ needed to coat the plates and the optimal concentrations of antibodies needed were determined by trial and error. Color reaction was generated with tetramethylbenzidine and measured in a plate reader. An example of the standard curve for TNF- $\alpha$ is shown in Fig. 2. TNF- $\alpha$ content of lavage fluids, perfusates, and serums was determined by use of this assay. Samples were run in triplicates, and values were used if the color reaction that was generated fell on the steep portion of the curve.

Determination of TNF- $\alpha$ receptor binding. Cell membranes were isolated from homogenized lungs as described previously. ${ }^{30}$ Extracted membranes were heat- 
denatured with 2-mercaptoethanol to expose protein binding sites. The protein content of the membrane extract was determined, and equal amounts of protein were blotted on nitrocellulose filters. The filters were blocked with a gelatin/bovine serum albumin protein solution and then incubated successively with mouse TNF- $\alpha$ (10 ng/ml), goat-antimouse TNF- $\alpha$ antibody (1: 1000 dilution), rabbit-antigoat immunoglobulin $\mathrm{G}$ conjugated to horseradish peroxidase (1:3600 dilution), and tetramethylbenzidine. Each incubation was conducted for 1 hour at $37^{\circ} \mathrm{C}$, and the color reaction was allowed to proceed at room temperature. The color reaction was measured with a densitometer.

Statistical analysis. Postpneumonectomy measurements were compared with those obtained from sham-operated animals by means of the Wilcoxon two-sample rank sum test for nonparametric comparisons. ${ }^{31}$

\section{Results}

\section{Changes in lung growth parameters}

Changes in dry lung weight. As shown in Table I, there was a slight, statistically insignificant increase in the size of each lung portion in the shamoperated animals between days 0 and 14 . This is consistent with the normal small rate of growth of these adult lungs. The right lungs of rats that had undergone left pneumonectomy significantly increased in total dry weight between day 0 and day 14 (see Table I). The weight of the $\mathrm{C}$ lobe increased 2.5-fold, and the $\mathrm{R}$ lobes doubled in dry weight.

Changes in DNA content. Table II shows changes in DNA content in both lung portions after pneumonectomy. DNA content in each portion of the lung showed a significant increase over the comparable measure in the sham-operated animals. The increase in DNA content was commensurate with the increase in total lung weight.

Changes in DNA synthesis. Cellular proliferative activity, as measured by ${ }^{3} \mathrm{H}$-thymidine uptake per milligram of DNA, was not different between shamoperated animals and control animals that received no operation and were killed on day 0 of the experiment (Table III). In contrast, cellular proliferative activity showed a statistically significant increase in both portions of the lung compared with the respective portions of sham-operated animals. There was no difference in DNA synthesis between the $\mathrm{C}$ and $\mathrm{R}$ portions of the operated lungs, which indicates that all lung portions showed equivalent rates of growth irrespective of location.

Changes in tyrosine kinase activity. Tyrosine kinase activity in sham-operated and postpneumonectomy lungs showed the same pattern observed with DNA synthesis (Table IV). There was no

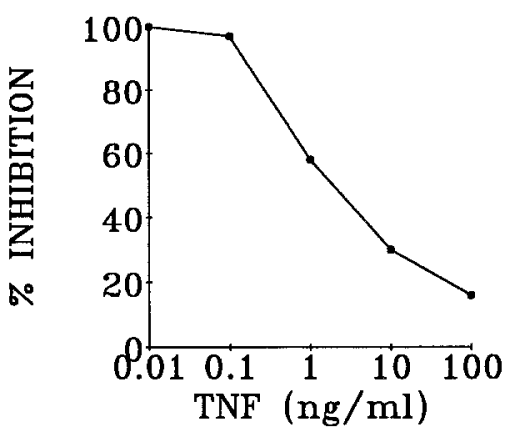

Fig. 2. Shape of a typical enzyme-linked immunosorbent assay standard curve. TNF- $\alpha$ concentrations are plotted on a semilog scale. Percent inhibition is calculated as the ratio of optical density associated with specific TNF- $\alpha$ concentration to that associated with the smallest TNF- $\alpha$ concentration used $(0.01 \mathrm{ng} / \mathrm{ml})$. Background and blank optical densities are electronically subtracted from all measured optical densities.

difference in activity between sham-operated animals and control animals that underwent no operation. However, postpneumonectomy lungs displayed a fourfold increase in tyrosine kinase activity, an increase which was statistically significant when compared with that of sham-operated animals. There was no difference in tyrosine kinase activity between the $\mathrm{C}$ lobe and the $\mathrm{R}$ lobes of the right lung, which again suggests that growth is not influenced by the location of the lobe undergoing growth.

Changes in total lung protein content. Total lung protein content corrected for DNA content increased slightly in the sham-operated animals (Table V). The further increase noted in the postpneumonectomy lungs was not statistically significant. In addition, there was no difference in protein content between the $\mathrm{C}$ and $\mathrm{R}$ portions of the lungs.

Changes in lung volume. Lung volumes measured 14 days after operation are shown in Fig. 3. The C lobes of the postpneumonectomy animals, located in the left hemithorax with additional expansion space resulting from left pneumonectomy, underwent larger increases in volume than the $\mathrm{R}$ lobes. The mean increase in the size of $\mathrm{C}$ lobes was $133 \%$ and that of $\mathrm{R}$ lobes was $59 \%$.

Changes in production of TNF- $\alpha$ after pneumonectomy

Changes in lavage fluid $T N F-\alpha$. Total lung lavage fluid TNF- $\alpha$ is shown in Fig. 4. Lavage TNF- $\alpha$ levels in sham-operated animals that were killed on day 7 
Table I. Dry lung weights (gm)

\begin{tabular}{lcccc}
\hline & C & $\begin{array}{c}p \\
\text { (versus day 0) }\end{array}$ & $\begin{array}{c}p \\
\text { (versus day 0) }\end{array}$ \\
\hline Day 0 $(n=5)$ & $0.018 \pm 0.0031$ & N/A & $0.094 \pm 0.0061$ & N/A \\
Day 14: Sham $(n=5)$ & $0.021 \pm 0.0021$ & NS & $0.104 \pm 0.0064$ & NS \\
Day 14: Pneumonectomy $(n=7)$ & $0.053 \pm 0.0034$ & 0.001 & $0.203 \pm 0.0068$ & 0.018 \\
\hline
\end{tabular}

$C$, Cardiac lobe; $N / A$, not applicable; $N S$, not significant; $R$, noncardiac lobes.

Table II. Total lung DNA content ( $m g$ )

\begin{tabular}{lcc}
\hline & $C$ & $R$ \\
\hline Day 0 $(n=4)$ & $0.297 \pm 0.032$ & $1.17 \pm 0.35$ \\
Day 14: Sham $(n=4)$ & $0.468 \pm 0.21$ & $2.19 \pm 0.64$ \\
Day 14: Pneumonectomy $(n=4)$ & $1.27 \pm 0.34$ & $4.36 \pm 0.68$ \\
$p$ (Sham vs. pneumonectomy) & 0.014 & 0.014 \\
\hline
\end{tabular}

Table III. Lung DNA synthesis (cpm/mg DNA)

\begin{tabular}{lccc}
\hline & $C$ & $R$ & $\begin{array}{c}p \\
(C \text { versus } R)\end{array}$ \\
\hline Day 0 $(n=4)$ & $37.2 \pm 7.43$ & $31.1 \pm 17.4$ & 0.243 \\
Day 14: Sham $(n=3)$ & $35.4 \pm 4.36$ & $27.3 \pm 4.81$ & 0.243 \\
$\begin{array}{l}\text { Day 14: Pneumonectomy } \\
\quad 58.6 \pm 15.2\end{array}$ & $64.5 \pm 31.3$ & 0.531 \\
$\quad(n=6)$ & & & \\
$p$ (Sham vs. & 0.012 & 0.01 & \\
$\quad$ pneumonectomy) & & & \\
\hline
\end{tabular}

were not different from those of animals killed on day 14. Sham-operated animals at both time points were pooled together and are represented by the 0 point on the graph. Compared with sham-operated animals, pneumonectomized rats had more than a 3.5-fold increase in their total lung lavage fluid TNF- $\alpha$ on day 7 . By day 14 , the increase in lung lavage fluid TNF- $\alpha$ was of a smaller magnitude but still statistically significant.

Changes in perfusate TNF- $\alpha$. TNF- $\alpha$ released into the perfusate of sham-operated and postpneumonectomy lungs is shown in Fig. 4. There was no increase in TNF- $\alpha$ release into the perfusate on days 7 or 14 after pneumonectomy, compared with the levels in the pooled sham-operated animals (represented by the 0 point on the graph).

Changes in serum $T N F-\alpha$. Fig. 5 depicts changes in serum TNF- $\alpha$ in the postpneumonectomy period. Small levels of circulating TNF- $\alpha$ were detected in sham-operated animals. These levels were increased more than twofold in animals killed on day 7 after lung resection. By day 14, TNF- $\alpha$ levels in the sera of postpneumonectomy animals were smaller and not statistically different from those in sham-operated animals.
Table IV. Lung tyrosine kinase activity (pmol ${ }^{32} \mathrm{P} / \mathrm{mg}$ protein)

\begin{tabular}{lccc}
\hline & \multicolumn{1}{c}{$c$} & $\begin{array}{c}p \\
\text { (C versus } R)\end{array}$ \\
\hline Day 0 $(n=4)$ & $1651 \pm 630$ & $1893 \pm 777$ & 0.43 \\
Day 14: Sham $(n=4)$ & $1558 \pm 279$ & $1885 \pm 809$ & 0.243 \\
Day 14: Pneumonectomy & $4003 \pm 2144$ & $4093 \pm 882$ & 0.35 \\
$\quad(n=5)$ & & & \\
$p$ (Sham vs. & & & \\
$\quad$ pneumonectomy) & 0.029 & 0.008 & \\
\hline
\end{tabular}

Table V. Lung protein content ( $m g / m g D N A)$

\begin{tabular}{lcc}
\hline & $C$ & $R$ \\
\hline Day 0 $(n=4)$ & $5.7 \pm 2.7$ & $8.37 \pm 9.5$ \\
Day 14: Sham $(n=4)$ & $21.3 \pm 4.30$ & $20.6 \pm 2.48$ \\
Day 14: Pneumonectomy $(n=4)$ & $37.9 \pm 13.3$ & $33.0 \pm 14.4$ \\
$p$ (Sham vs. pneumonectomy) & 0.114 & 0.057
\end{tabular}

Changes in binding of TNF- $\alpha$ after pneumonectomy. Densitometric scans of immunoblots of homogenized lung membranes are shown in Fig. 6. The bottom graph shows that TNF- $\alpha$ binding by shamoperated animal lungs did not change in the postoperative period. In contrast, TNF- $\alpha$ binding in pneumonectomized animals demonstrated a gradual increase throughout the study period (top graph). On day 7, TNF- $\alpha$ binding in these animals was more than that demonstrated by sham-operated animals, and there was a further increase in binding by day 14 .

\section{Discussion}

In this study, the degree of expansion of different portions of the lung was influenced by the anatomic location and the availability of potential space into which expansion could occur. For example, the C lobe of the right lung, which is located in the left hemithorax, has more expansion space available after left pneumonectomy than the $\mathrm{R}$ lobes. This is verified by the $133 \%$ increase in mean $\mathrm{C}$ lobe volume 14 days after surgery, compared with only a $59 \%$ increase in the volume of the R lobes. There 


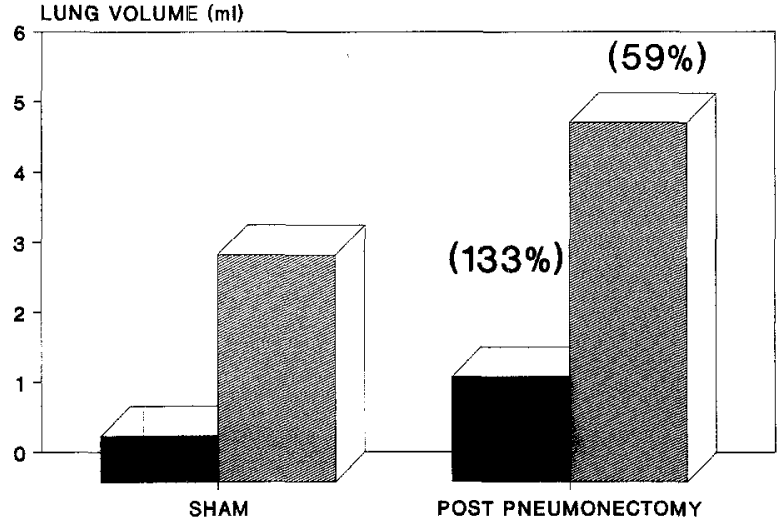

Fig. 3. Volumes of the cardiac lobes (solid bars) and the other three right lung lobes (shaded bars) 14 days after operation. The numbers in parentheses represent the percent increase in volume for a pneumonectomized rat (right) versus a sham-operated rat (left).

were no differences between the $\mathrm{C}$ and $\mathrm{R}$ lobes in other growth parameters. Specifically, the increases in the weight, DNA content, protein content, DNA synthesis, and tyrosine kinase activity observed in the $\mathrm{C}$ lobe were proportional to those of the $\mathrm{R}$ lobes.

Because the growth was uniform irrespective of the anatomic location of the lobe, global stimuli such as humoral factors produced by the growing lung or circulating into the lung from distant sources may have had a dominant role in regulation of postpneumonectomy lung growth. This hypothesis has been proposed by other researchers who, using autoradiographic techniques, demonstrated that different lobes of the right lung had equal percentages of dividing cells after left pneumonectomy. ${ }^{25}$ The role of natural hormones in lung growth has previously been suggested by other investigators. ${ }^{32-34}$. These hormones have been shown to play a role in normal prenatal and postnatal lung growth. ${ }^{35}$ In addition, other studies have shown that postpneumonectomy lungs are characterized by high ratios of adenylate cyclase to cyclic adenosine monophosphate phosphodiesterase, ${ }^{36}$ and that compensatory growth is preceded and accompanied by increased activity of cyclic adenosine monophosphate-dependent enzymes ${ }^{36}$ that correlate with natural hormone activity. Higher circulating levels of growth hormone have been observed in the postpneumonectomy period. ${ }^{25}$ Rannels and associates ${ }^{24}$ demonstrated, using morphometric techniques, that endogenous adrenal corticosteroids are important in regulation

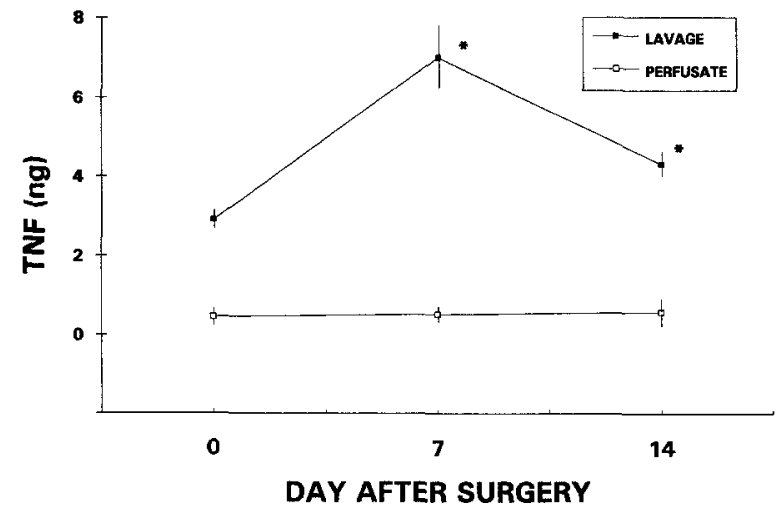

Fig. 4. Changes in levels of total lung lavage fluid TNF- $\alpha$ and perfusate TNF- $\alpha$ after pneumonectomy. The 0 time point on the abscissa represents the mean of 6 shamoperated animals (three killed on day 7 and three on day 14) in each case. Points shown for days 7 and 14 represent results for five and eight pneumonectomized animals, respectively. Values are means and standard errors. Asterisk indicates statistically significant difference from sham-operated animals $(p<0.05)$.

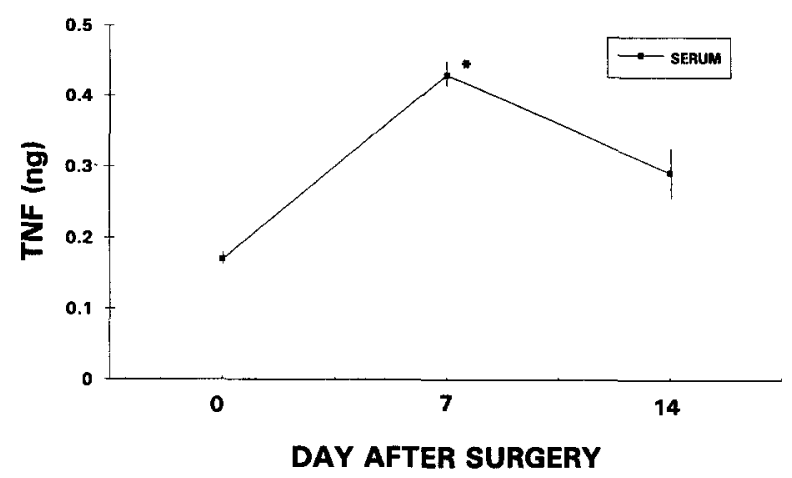

Fig. 5. Changes in serum TNF- $\alpha$ after pneumonectomy. The 0 time point on the abscissa represents the mean of 6 sham-operated animals (three killed on day 7 and three on day 14). For postpneumonectomy animals, $n=4$ on day 7 and day 14. Points shown represent means and standard errors. Asterisk indicates statistically significant difference from shams $(p<0.05)$.

of postpneumonectomy lung growth. Last, injection of MtTF4 tumor cells, which results in the production of excessive amounts of natural hormones, including growth hormones, is associated with acceleration of postpneumonectomy lung growth. ${ }^{33}$ In addition to natural hormones, local growth factors may be implicated. Numerous cytokines and growth factors are known to be produced by the lung and to have mitogenic effect on its parenchymal cells. ${ }^{37-42}$ 


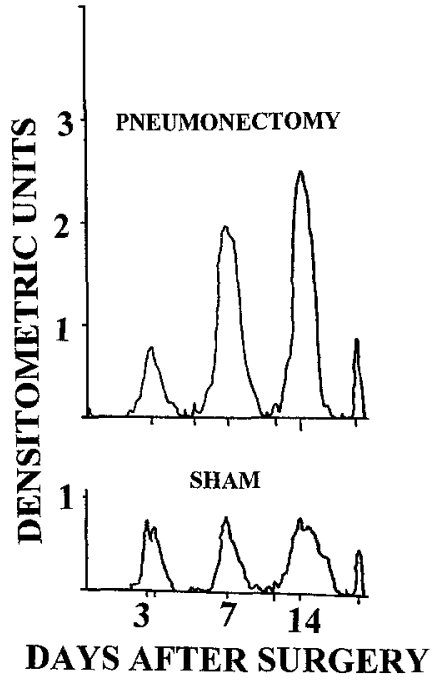

Fig. 6. Densitometric scan of immunoblots of postpneumonectomy lungs (top) and sham-operated lungs (bottom). The peak is a measure of the intensity of the color reaction generated after allowing excess exogenous TNF- $\alpha$, TNF- $\alpha$ antibody, and peroxidase-conjugated secondary antibody to bind to lung homogenates on nitrocellulose filters. The color reaction is generated by the addition of tetramethylbenzidine in the presence of hydrogen peroxide and citric acid and is proportional to the TNF- $\alpha$ binding capacity of the lung homogenate. Note lack of change in TNF- $\alpha$ binding capacity after shamoperations and the gradual increase in TNF- $\alpha$ binding after pneumonectomy.

Some are thought to be produced in the postpneumonectomy period. ${ }^{23,25-27}$

The implication of hormones, cytokines, and other growth factors in regulation of postpneumonectomy lung growth does not preclude an important role for mechanical factors, such as stretch, in this process. Numerous investigators have emphasized the role of stretch in mediation of this phenomenon. ${ }^{7,43-48}$ The interest in stretch is based on the similarities between the postpneumonectomy lung and the neonatal lung. ${ }^{49}$ In the neonate, the ability of the lung to expand into the thoracic cavity has been proposed as an important regulator of lung growth, because of the fact that the presence of congenital diaphragmatic hernia results in hypoplastic lungs, whereas the intrauterine repair of diaphragmatic hernia results in normal lung growth and development. ${ }^{50,51}$

How can one reconcile the observation that stretch is important in mediation of the growth response with the observation that humoral factors are intimately involved in this process? The answer can be as simple as proposing a multifactorial process involving both stretch and humoral factors. However, a more interesting reconciliation has been suggested by a recent study that investigated the role of stretch at the cellular level. Bishop and colleagues $^{52}$ subjected fibroblasts grown on silicone rubber membranes to various degrees of stretch and measured the rate of growth of these cells as well as the mitogenic ability of conditioned media collected from these cells. Stretch was found to alter cell function, resulting in the secretion of mitogenic factors, the nature of which has yet to be determined. This study suggests that stretch may be important in promoting postpenumonectomy lung growth by inducing the release of a number of endogenous cytokines (primarily produced by alveolar macrophages) by the growing lung.

Whether TNF- $\alpha$ is such a cytokine produced in the postpneumonectomy period, and whether it influences the repair process, are questions that have not been previously addressed. We are interested in TNF- $\alpha$, a cytokine believed to promote cellular multiplication and matrix synthesis in other models of lung repair. In mice, bleomycin administration increases the steady-state levels of TNF- $\alpha$ messenger ribonucleic acid (mRNA) in lung tissue. ${ }^{21}$ The increase in the expression of the TNF- $\alpha$ gene precedes that of collagen, suggesting that prior activation of TNF- $\alpha$ synthetic pathways may be instrumental in promoting the synthesis of this matrix component. This was further supported by Piguet and coworkers, ${ }^{22}$ who demonstrated increased TNF- $\alpha$ mRNA starting on day 5 after bleomycin instillation in rats. ${ }^{22}$ These authors were able to prevent the development of bleomycin lung fibrosis in mice by pretreating the animals with specific antimouse TNF- $\alpha$ immunoglobulin G.

Does TNF- $\alpha$ play a role in postpneumonectomy lung growth? Our data indicate that after pneumonectomy there is a significant increase in the production of TNF- $\alpha$, the bulk of which appears to be released onto the alveolar surface and recovered by lavage. What is the significance of increased TNF- $\alpha$ in the lavage fluid? It is possible that this is just an epiphenomenon in animals stressed by the recent loss of a major organ. However, if increased TNF- $\alpha$ production is mainly related to the level of stress of the animals, then serum and lavage fluid TNF- $\alpha$ levels would be expected to show similar patterns of change. In this study, however, serum TNF- $\alpha$ was significantly elevated only on day 7 after surgery, 
whereas lavage fluid TNF- $\alpha$ remained significantly elevated throughout the study period. In addition, the increased binding capacity of the postpneumonectomy lungs and the direction of change in binding capacity are other clues that TNF- $\alpha$ may be playing a role in the repair process. The TNF- $\alpha$ binding capacity increased gradually in the postoperative period from day 3 to day 14 , a period during which the degree of stress of the animals would have been expected to gradually decline. The shamoperated animals did not demonstrate any changes in TNF- $\alpha$ binding, which indicates that stress alone is not the primary stimulus for TNF- $\alpha$ production.

In summary, left pneumonectomy is associated with uniform growth of the lobes of the right lung. This growth is associated with increased production and binding of TNF- $\alpha$ by the growing lung, which suggests a possible role for this cytokine in mediation of the growth process. This study emphasizes the role of endogenous cytokines, such as TNF- $\alpha$, in regulation of postpneumonectomy lung growth. Future studies should focus on the use of these factors in promoting compensatory lung growth and their effects on lung anatomy and function.

\section{REFERENCES}

1. Murray JF. The normal lung. Philadelphia: WB Saunders, 1986.

2. Hislop A, Reid L. Growth and development of the respiratory system. In: Davis JA, Dopping J, eds. Scientific foundations of paediatrics. London: Heinemann, 1974:214-54.

3. Langston C, Kida K, Reed LM. Human lung growth in late gestation and in the neonate. Am Rev Respir Dis 1984;129:607-13.

4. Burri PH. Fetal and postnatal development of the lung. Annu Rev Physiol 1984;46:617-28.

5. Thurlbeck WM. Postnatal growth and development of the lung. Am Rev Respir Dis 1975;111:803-44.

6. Polgar G, Weng TR. The functional development of the respiratory system: from the period of gestation to adulthood. Am Rev Respir Dis 1979;120:625-95.

7. Cagle PT, Thurlbeck WM. Postpneumonectomy lung growth. Am Rev Respir Dis 1988;138:1314-26.

8. Rannels DE, White DM, Watkins CA. Rapidity of compensatory lung growth following pneumonectomy in adult rats. J Appl Physiol 1979;46:326-33.

9. Thet LA, Law DJ. Changes in cell number and lung morphology during early postpneumonectomy lung growth. J Appl Physiol 1984;56:975-8.

10. Brody JS, Burk R, Kaplan N. DNA synthesis in lung cells during compensatory lung growth after pneumonectomy. Am Rev Respir Dis 1978;117:307-15.

11. Das RM, Thurlbeck WM. The events in the contralat- eral lung following pneumonectomy in the rabbit. Lung 1979;156:165-72.

12. Thurlbeck WM, Galaugher W, Mathers J. Adaptive response to pneumonectomy in puppies. Thorax 1981; 36:424-7.

13. Thurlbeck WM. Post pneumonectomy compensatory lung growth. Am Rev Respir Dis 1983;128:965-7.

14. Carswell EA, Old LJ, Kassell RI, et al. An endotoxin induced serum factor that causes necrosis of tumors. Proc Natl Acad Sci U S A 1975;72:3666-70.

15. Kettelhut IC, Fiers W, Goldberg AL. The toxic effects of tumor necrosis in vitro and their prevention by cyclooxygenase inhibitors. Proc Natl Acad Sci U S A 1987;84:4273-7.

16. Beutler B, Cerami A. Cachectin: more than a tumor necrosis factor. N Engl J Med 1987;316:379-85.

17. Simpson SQ, Modi HN, Balk RA, et al. Reduced alveolar macrophage production of tumor necrosis factor during sepsis in mice and men. Crit Care Med 1991;19:1060-6.

18. Hass $P$, Hotchkiss A, Mohler M, et al. Characterization of specific high affinity receptors for human tumor necrosis factor on mouse fibroblasts. J Biol Chem 1986;260:12214-8.

19. Sugarman BJ, Hass PE, Figari JS. Recombinant human tumor necrosis factor-alpha: effects on proliferation of normal and transformed cells in vivo. Science 1985;236:943-45.

20. Elias JA, Krol RC, Freundlich B, et al. Regulation of human lung fibroblast glycosaminoglycan production by recombinant interferons, tumor necrosis factor, and lymphotoxin. J Clin Invest 1988;81:325-33.

21. Phan SH, Kunkel SL. Lung cytokine production in bleomycin-induced pulmonary fibrosis. Exp Lung Res 1992;18:29-43.

22. Piguet PF, Collart MA, Grau GF, et al. Tumor necrosis factor/cachectin plays a key role in bleomycin-induced pneumopathy and fibrosis. J Exp Med 1989;170:655-63.

23. Khadempour MH, Ofulue AF, Sekhon HS, Cherukupalli KM, Thurlbeck WM. Changes in growth hormone, somatomedin $\mathrm{C}$ and bombesin following pneumonectomy. Exp Lung Res 1992;18:421-32.

24. Rannels DE, Stockstill B, Mercer RR, Crapo JD. Cellular changes in the lungs of adrenalecomized rats following left pneumonectomy. Am J Respir Cell Mol Biol 1991;5:351-62.

25. Cagle PT, Langston C, Goodman JC, Thurlbeck WM. Autoradiographic assessment of the sequence of cellular proliferation in post-pneumonectomy lung growth. Am J Respir Cell Mol Biol 1990;3: 153-8.

26. Kuboi S, Mizuuchi A, Mizuuchi T, Taguchi T, Thurlbeck WM, Kida K. DNA synthesis and related enzymes altered in compensatory lung growth in rats. Scand J Clin Lab Invest 1992;52:707-15. 
27. Ofulue AF, Matsui $R$, Thurlbeck WM. The role of calmodulin as an endogenous initiatory factor in compensatory lung growth after pneumonectomy. Pediatr Pulmonol 1993;15:145-50.

28. Burton KA. A study of the conditions and mechanisms of the diphenylamine reaction for the colorimetric estimation of deoxyribonucleic acid. Biochem $\mathbf{J}$ 1956;62:313-26.

29. Bradford MM. A rapid and sensitive method for the quantitation of microgram quantities of protein utilizing the principle of protein dye binding. Anal Biochem 1976;72:248-54.

30. Dubaybo BA, Marwah GS, Fligiel SEG, Hatfield IS, Majumdar APN. Tyrosine kinase activation during lung injury, fibrosis, and compensatory growth. Exp Lung Res 1990;16:257-66.

31. Zar JH. Biostatistical analysis. 2nd ed. Englewood Cliffs, NJ: Prentice-Hall, 1984.

32. Brody JS, Buhain WJ. Hormonal influence on post pneumonectomy lung growth in the rat. Respir Physiol 1973;19:344-55.

33. Brody JS, Buhain WJ. Hormone-induced growth of the adult lung. Am J Physiol 1972;223:1444-50.

34. Bartlett D Jr. Postnatal growth of the mammalian lung: influence of excess growth hormone. Respir Physiol 1971;12:297-304.

35. Ballard PL. Hormone and Lung Maturation. Berlin: Springer-Verlag, 1986.

36. Najjar MS, Thurlbeck WM. Alterations in enzymes related to adenosine $3^{\prime}, 5^{\prime}$-monophosphate during compensatory growth of rat lung. Eur J Biochem 1980;105:403-7.

37. Bitterman PB, Wewers MD, Rennard SI, et al. Modulation of alveolar macrophage driven fibroblast proliferation by alternative macrophage mediators. J Clin Invest 1986;77:700-8.

38. Lemaire L, Beaudoin H, Massé S, et al. Alveolar macrophage stimulation of lung fibroblast growth in asbestos induced pulmonary fibrosis. Am J Pathol 122:205-11, 1986.

39. Martinet Y, Rom WN, Grotendorst GR, et al. Exaggerated spontaneous release of platelet derived growth factor by alveolar macrophages from patients with idiopathic pulmonary fibrosis. $\mathbf{N}$ Engl $\mathbf{J}$ Med 1987;317:202-9.
40. Scheule RK, Perkins RC, Hamilton R, Holian A. Bleomycin stimulation of cytokine secretion by the human alveolar macrophage. Am J Physiol 1992; 262(4 Pt 1):L386-91.

41. Everson MP, Chandler DB. Changes in distribution, morphology, and tumor necrosis factor-alpha secretion of alveolar macrophage subpopulations during the development of bleomycin-induced pulmonary fibrosis. Am J Pathol 1992;140:503-12.

42. Fabisiak JP, Absher M, Evans JN, et al. Spontaneous production of PDGF A-chain homodimer by rat lung fibroblasts in vitro. Am J Physiol 1992;263: L185-93.

43. Mizuuchi A. Morphological changes accompanying compensatory lung growth after pneumonectomy in rats. Jpn J Geriatr 1991;28:210-6.

44. Cowan MJ, Crystal RG. Lung growth after unilateral pneumonectomy: quantitation of collagen synthesis and content. Am Rev Respir Dis 1975;111:267-77.

45. Simnett JD. Stimulation of cell division following unilateral collapse of the lung. Anat Rec 1974;180: 681-6.

46. Fischer JM, Simnett JD. Morphogenetic and proliferative changes in the regenerating lung of the rat. Anat Rec 1973;176:389-96.

47. Inselman LS, Mellins RB, Brasel JA. Effect of lung collapse on compensatory lung growth. J Appl Physiol 1977;43:27-31.

48. Tratter PI, Goss RJ. Compensatory pulmonary hypertrophy after incapacitation of one lung in the rat. $\mathrm{J}$ THORAC CARDIOVASC SURG 1973;66:147-52.

49. Yee NM, Hyatt RE. Effect of left pneumonectomy on lung mechanics in rabbits. J Appl Physiol 1983;54: 1612-7.

50. De Lorimier A, Tierney DF, Parker HR. Hypoplastic lungs in fetal lambs with surgically produced congenital diaphragmatic hernia. Surgery 1967;62:12-7.

51. Kitagawa M, Hislop A, Boyden EA, Reid L. Lung hypoplasia in congenital diaphragmatic hernia: a quantitative study of airway, artery, and alveolar development. Br J Surg 1971;58:342-6.

52. Bishop JE, Mitchell JJ, Absher M, et al. Cyclic mechanical deformation stimulates human lung fibroblast proliferation and autocrine growth factor activity. Am J Respir Cell Mol Biol 1993;9:126-33. 